\title{
OVERVIEW OF THE UKRAINIAN SOLAR MARKET: STATUS AND COMMERCIAL PERSPECTIVES
}

\author{
R. ZAITSEV ${ }^{1^{*}}$, K. MINAKOVA ${ }^{2}$ \\ ${ }^{1}$ Materials for Electronics and Solar Cells Department, National Technical University "Kharkiv Polytechnic Institute”, Kharkiv, \\ UKRAINE \\ ${ }^{2}$ Physics Department, National Technical University “Kharkiv Polytechnic Institute”, Kharkiv, UKRAINE \\ "e-mail: zaitsev@khpi.edu.ua
}

ABSTRACT Today, solar energy is called the energy of the future, and many companies make significant investments in the construction of such power plants. The article provides an overview of the commercial perspectives of this market, determines the size of investments and the return on the project. Modern solar panels are able to operate without additional investments for decades and, from the point of view of the authors, in the long term the electricity generated in this way will not only cost-effective, and extremely profitable. The global situation in the energy market and in the field of renewable energy, in particular, is considered. The reasons that triggered the development of renewable energy sources, the key of which are the dangers of nuclear energy and environmental pollution, are explained. Along with this, we consider the structure of the market of renewable energy sources in Ukraine, where the geographic location is favorable for the implementation of solar energy projects. The climate of Ukraine is characterized by a large number of sunny days: in terms of insolation, Ukraine is significantly superior to European leaders in solar energy. This basic factor allows us to talk about the commercial perspectives of solar power generation projects implemented in Ukraine. Against the background of these perspectives is considered the structure of the energy market in Ukraine and the investment attraction of renewable energy projects. Market trends in the development of the solar energy market were discussed, which are expected to contribute to the development of new market niches, such as after-sales services, as well as the transformation of existing business models against the backdrop of the introduction of new facilities.

Keywords: solar energy; renewable energy sources; Ukrainian market overview; commercial perspectives

\section{ОГЛЯД РИНКУ СОНЯЧНОЇ ЕНЕРГЕТИКИ УКРАЇНИ: СТАН ТА КОМЕРЦЙНІ ПЕРСПЕКТИВИ}

\section{Р. В. ЗАЙЦЕВ ${ }^{1^{*}}$, К. О. МІНАКОВА ${ }^{2}$}

\author{
${ }^{1}$ Кафедра фізичного матеріалознавства для електроніки та геліоенергетики, Національний технічний університет \\ «Харківський політехнічний інститут», Харків, УКРАЇНА \\ ${ }^{2}$ Кафедра фізики, Національний технічний університет «Харківський політехнічний інститут», Харків, УКРАЇНА
}

\begin{abstract}
АНОТАЦІЯ Сьогодні багато хто називає сонячну енергію енергією майбутнього, $і$ багато компаній вкладають значні інвестииії в будівництво таких електростанцій. У статті наведено огляд комериійних перспектив иъього ринку, визначені розміри інвестицій і окупність проекту. Сучасні сонячні батареї в змозі праџювати без додаткових капіталовкладень десятки років $i$, з точки зору авторів, в довгостроковій перспективі електроенергія, згенерована таким чином, стане не просто рентабельною, а надприбутковою. У статті розглянута глобальна ситуація в сфері ринку енергетики $і$ в сфері відновлюваних джерел енергії, зокрема. Пояснені причини, які послужсили поштовхом у розвитку відновлюваних джерел енергї̈, ключовими з яких є небезпека атомної енергетики і забруднення навколишнього середовища. На ряду з зазначеним, розглянута структура ринку відновлюваних джерел енергії на Україні, географічне розташування якої сприятливо для реалізачії проектів сонячної енергетики. Для клімату України характерна велика кількість сонячних днів: за ступенем інсолячії Украӥна значно перевериує європейських лідерів в сонячній енергетичі. Зазначене є базовим фактором, що дозволяє говорити про комериійні перспективи проектів сонячної електрогенерачії, щзо реалізуються в Украӥні. На тлі зазначених перспектив розглянута структура енергетичного ринку на Україні і інвестиційна привабливість проектів відновлюваної енергетики. Обговорено ринкові тенденції розвитку ринку сонячної енергетики, які, як очікується, на тлі введення нових об'єктів сприятимуть розвитку нових ринкових ніш, таких як сервісне обслуговування, а також трансформачї існуючих бізнес-моделей.
\end{abstract}

Ключові слова: сонячна енергетика; відновлювані джерела енергї̈; огляд ринку України; комерційні перспективи

\section{The global situation in the field of power generation from renewable energy sources}

After the world felt the whole danger of nuclear energy and became infected with the idea of getting energy from renewable sources, such as sunlight and wind, a river of funding surged in that direction. The effect was not long in coming: in two decades, the efficiency of solar panels, battery power and reliability of wind generators increased sharply, and their cost decreased significantly.

Today, many calls solar energy the energy of the future, and many companies make significant investments in the construction of such power plants. Modern solar cells are able to operate without additional investment for decades and, in our opinion, in the long term, the 
electricity generated in this way will become not only cost-effective, but also extremely profitable.

Renewable energy sources (RES), which are usually attributed to the energy of the sun, water, wind, biomass, demonstrate a positive dynamic in the share in the global energy balance.

This is due to the following circumstances:

- the fight against global warming is becoming more and more systematic. The Paris Climate Change Agreement outlines specific measures to reduce greenhouse gas emissions;

- the development of electricity generation based on renewable energy sources has targeted support from states, tariff and tax incentives allow competing with generation based on traditional energy sources;

- the cost of photovoltaics (the main technology of power generation using solar panels) is reduced - the cost of solar panels in the world is reduced by $10 \%$ annually.

Solar energy is considered the most promising direction of the energy industry, since in recent years, market prices for solar modules have significantly decreased, and their efficiency has been increasing. According to the statistical report of British Petroleum [1], by the end of 2017, the total installed power of solar power plants built and commissioned worldwide exceeded $400 \mathrm{GW}$ (Fig. 1). This power is generated at the expense of 301500 solar power plants (SPP). It is noteworthy that $48 \%$ of them are in Asia. The indicator of the total installed power demonstrates stable positive dynamics over a long period. According to the report of the International Energy Agency [2], in 2018-2019 this figure will increase by 100-150 GW per year.

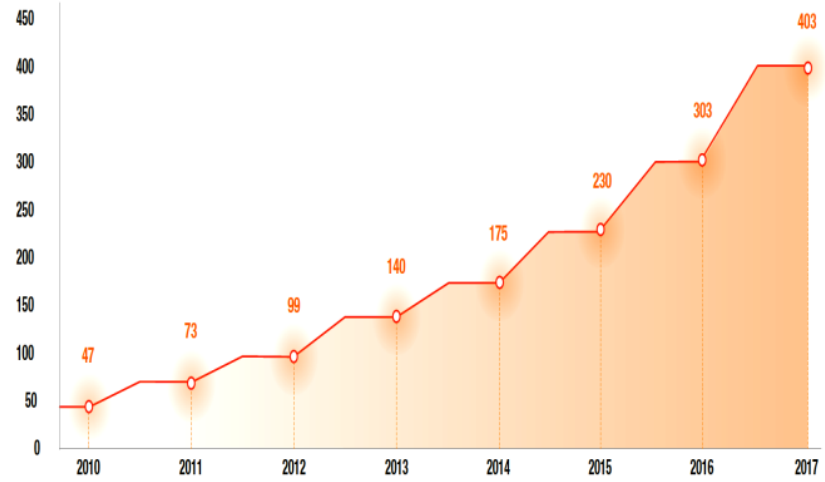

Fig. 1 - The dynamics of the total installed power of solar power plants in the world, $G W$

Intensification of growth in the number of SPP and increasing the share of energy generated by them in the overall balance - a problem that is solved on the level of state policy. As a rule, the cost of renewable energy generation exceeds the cost of energy from traditional sources, and it is possible to bring new players to the market only with systemic support from states. Over the past 10 years, the leading positions in SPP-based power generation have belonged to Germany and Italy; however, thanks to the implementation of large-scale programs to stimulate solar energy (Table 1), the list of leaders has been expanded by countries such as China, the USA and Japan (Fig. 2).

Table 1 - Regional features of incentive policies RES

\begin{tabular}{|c|c|c|c|}
\hline Parameter & EU & USA & China \\
\hline RES share & $\begin{array}{l}\text { In final consumption - } \\
16.7 \% \text { as of } 2015\end{array}$ & $\begin{array}{l}\text { The total share of all RES } \\
\text { reached } 19.4 \% \text { as of } 2016 \text {. }\end{array}$ & $\begin{array}{l}\text { The share of green energy exceeds } \\
35 \% \text { of the total installed power in } \\
\text { the country as of } 2016 \text {. }\end{array}$ \\
\hline $\begin{array}{l}\text { Features of } \\
\text { stimulation }\end{array}$ & $\begin{array}{l}\text { - establishment of a } \\
\text { preferential price for the } \\
\text { purchase of electricity } \\
\text { generated using RES; } \\
\text { - trade in green } \\
\text { certificates based on } \\
\text { quotas for the } \\
\text { consumption of electricity } \\
\text { generated using RES. }\end{array}$ & $\begin{array}{l}\text { - federal measures to } \\
\text { support solar energy in the } \\
\text { form of a } 30 \% \text { investment tax } \\
\text { credits. }\end{array}$ & $\begin{array}{l}\text { - purchase of clean electricity at } \\
\text { preferential and full tariffs; } \\
\text { • creation of funds to finance } \\
\text { development in the field of RES; } \\
\text { - adoption of renewable energy } \\
\text { priority development programs, in } \\
\text { particular, Document } 625 \text {, } \\
\text { according to which the minimum } \\
\text { amount of mandatory consumption } \\
\text { of renewable energy by large grid } \\
\text { companies is established. }\end{array}$ \\
\hline $\begin{array}{l}\text { Prediction for } \\
\text { achieving the } \\
\text { share of RES }\end{array}$ & $\begin{array}{l}\text { By 2020, RES will } \\
\text { account for about } 20 \% \text { of } \\
\text { the energy supply. While } \\
\text { only } 6 \text { EU countries had } \\
\text { fulfilled their } \\
\text { commitments. }\end{array}$ & $\begin{array}{l}\text { In } 2015 \text {, the US Department of } \\
\text { Energy's statistical division } \\
\text { projected an increase in the } \\
\text { share of RES from } 13 \% \text { in } \\
2013 \text { to } 18 \% \text { in } 2040 . \text { Actual } \\
\text { development is ahead of } \\
\text { prediction for a decade. }\end{array}$ & $\begin{array}{l}\text { It was predicted that by } 2020 \text {, RES } \\
\text { will account for about } 15 \% \text { of the } \\
\text { energy supply, but the goal for solar } \\
\text { energy has already been achieved, } \\
\text { and by the end of } 2019 \text { it is planned } \\
\text { to fulfill the norm for wind } \\
\text { electricity. }\end{array}$ \\
\hline
\end{tabular}




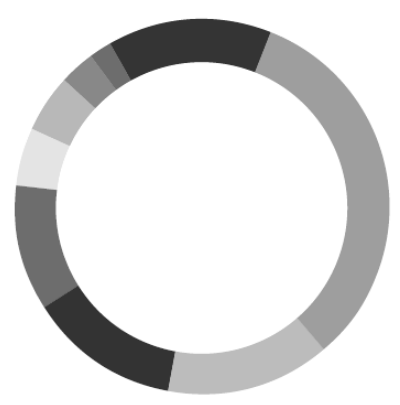

\begin{tabular}{|ll}
$33 \%(125,0)$ & China \\
$14 \%(52,8)$ & USA \\
$\mathbf{1 3} \%(\mathbf{4 9 , 6 )}$ & Japan \\
$\mathbf{1 1}(\mathbf{4 1 , 2 )}$ & Germany \\
$5 \%(19,0)$ & India \\
$5 \%(19,3)$ & Italy \\
$\mathbf{3} \%(11,6)$ & Great Britain \\
$\mathbf{2} \%(\mathbf{7 , 1})$ & France \\
$\mathbf{1 4 \% ( 5 3 , 7 )}$ & Others
\end{tabular}

Fig. 2 - Geographical structure of power generation based on SPP as of the end of 2017, GW

A renewable energy incentive policy exists in 85 countries. Moreover, programs in this area are being developed both at the national level and at the level of individual regions and territories. Typology of measures varies from preferential rates and loans to training and internships. For the most part, the main goal of national renewable energy incentive policies is to achieve a certain share of renewable energy in the total balance of electricity generation (from 5 to $30 \%$ ). In a number of cases, it is specified that the share of renewable energy should increase in the structure of final consumption (from 10 to $20 \%$ ).

At the global level, we can talk about several approaches to stimulate the development of solar energy. As a rule, in countries with developed economies, where solar energy has mainly reached targets, support for the development of photovoltaics is gradually moving away from direct incentive measures for the following reasons:

- The cost of generation based on photovoltaics has declined significantly in recent years. According to Lazard's LCOE (Levelized Cost of Electricity) estimates, for wind and sun this indicator decreased over the period $2010-2017$. $66 \%$ and $85 \%$ respectively, which equates to the parameters for gas and coal. As a result, the cost of generation makes such projects competitive with traditional fuels and without government support.

- Tariff regulated selling price of energy from RES is higher compared to the cost of energy from traditional sources. As a rule, the current policy obliges distribution network operators in European countries to conclude contracts for the supply of such energy for a long period (of 10 years) with a fixed price. For example, in Germany, contracts awarded 10 years ago are bought at 45-50 cents per kilowatt, while the current market price for a kilowatt of solar energy in Germany is about 12 cents.

In many respects, these circumstances caused the pace of development of photovoltaics in the EU and the US to slightly decrease. Against this background, solar generation in China, stimulated by the state in every way, demonstrates the highest rates of development. At the same time, China is actively developing the industry for the production of components for SPP, including photovoltaic elements. State support allows Chinese suppliers to maintain price leadership in the global market by minimizing the cost of products.

International structures have a relatively small impact on stimulating the development of solar energy on a global scale. The most significant organization in this area is the International Energy Agency (IEA) and the International Renewable Energy Agency (IRENA), whose activities include analytical work, information exchange and the development of international cooperation [4].

The power indicator is called the main one in the world when evaluating the market, but the amount of investment is no less important. According to Bloomberg New Energy Finance [5], in 2016 it amounted to \$ 242 billion, which is $23 \%$ less than in the previous year. Of these, 114 billion US dollars accounted for the solar energy segment with a decline of $34 \%$ compared with the previous year, due to the previously indicated reduction in the cost of such projects. According to Frost \& Sullivan [6], in 2017 the volume of investments in renewable energy sources will amount to 243 billion US dollars, of which 142 billion US dollars will be spent on solar energy.

Further development of the market will be driven by the following trends.

- Global trends:

○ According to IEA prediction, until 2022 the total power of renewable energy sources will increase by more than $920 \mathrm{GW}$, which is 3 times higher than the same indicator in 2016;

$\circ$ Wind and sun will represent more than $80 \%$ of the global renewable energy market growth over the next five years.

- Regional trends:

O China: the total installed power of RES by the end of 2022 will increase by 63.6\% compared with 2017 . Also, in May 2018, the construction of the world's largest floating SPP with a power of $150 \mathrm{MW}$ will be completed;

○ USA: uncertainty about the prospects for federal tax reform in the context of the implementation of incentive RES;

○ EU: transition from state support (refusal of financial stimulation of RES implementation) to a more competitive market;

○ Developing countries in sub-Saharan Africa and Africa: growth of off-grid solar photovoltaic applications - according to IEA prediction, by 2022 off-grid power will increase to 3 thousand MW, which is 3 times more than in 2017.

- Regulatory trends:

○ The transition from the "green" tariffs to competitive auctions and long-term agreements on the purchase of electricity for utilities.

\section{The structure of the renewable energy market in} Ukraine

The geographical location of Ukraine is favorable for the implementation of solar energy generation projects [7]. The climate of Ukraine is characterized by a large 
number of sunny days: in terms of insolation, Ukraine significantly exceeds Germany, the recognized European leader in solar energy. This basic factor allows us to talk about the commercial prospects of solar power generation projects implemented in Ukraine [8]. The state also declares all possible support for renewable energy projects. However, in practice, the implementation of such projects requires taking into account a number of nuances, without which the initiator of the project may face serious limitations and the risk of not reaching targets.

In Ukraine, solar energy over the past 5 years has evolved from a small segment represented by several pilot projects into one of the largest rapidly growing areas. According to the American company IB Center Inc. [9], the capitalization of the Ukrainian solar energy market in 2016 exceeded \$ 1.4 billion.

However, political instability, which reached its peak in 2014, the ensuing devaluation of the hryvnia, the continuing aggravation of the risks of military conflict in the east of the country had a negative impact on investment projects direction. As a result of the annexation of the Crimea has been temporarily lost the most favorable in terms of the use of renewable energy region in which up to 2014 had already been successfully implemented such projects.

In 2014, the Energy and Utilities the National Regulatory Commission (NKREKU) implementing state regulation in the fields of energy and utilities [10] did not compensate representatives of alternative energy for losses from exchange rate differences, and "green" tariffs were reduced at the legislative level. As a result, the intensity of commissioning of new SPP has noticeably decreased (Fig. 3).

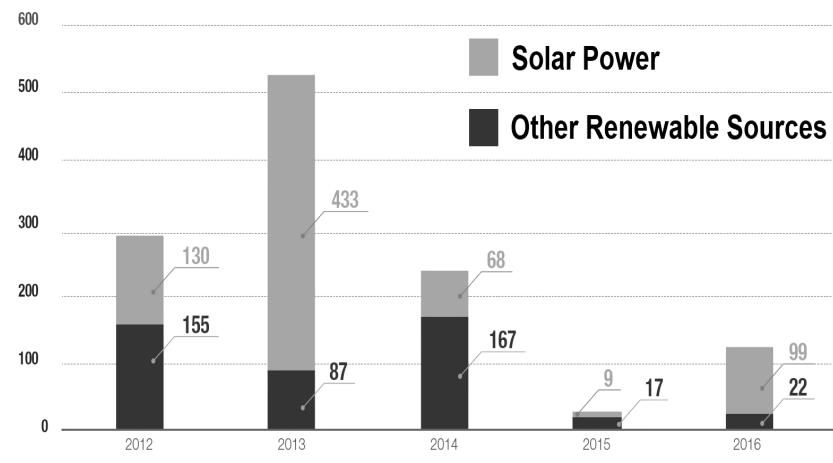

Fig. 3 - Dynamics of commissioning of renewable energy stations, $M W$

In 2016, there was a resumption of positive dynamics, with projects related to photovoltaics showing the greatest growth. In 2015, Law No. 514-VIII "On Amending Certain Laws of Ukraine Regarding Ensuring Competitive Conditions for the Production of Electric Power from Alternative Energy Sources" was adopted. Thus, there was a legal framework aimed at attracting investments in Ukraine, because the Law №514-VIII, tied the "green" tariff in euros [11].
According to the State Agency for Energy Efficiency and Energy Saving of Ukraine [12], as of October 1, 2017, there are 359 renewable energy facilities operating in the country with a total power of $1320 \mathrm{MW}$.

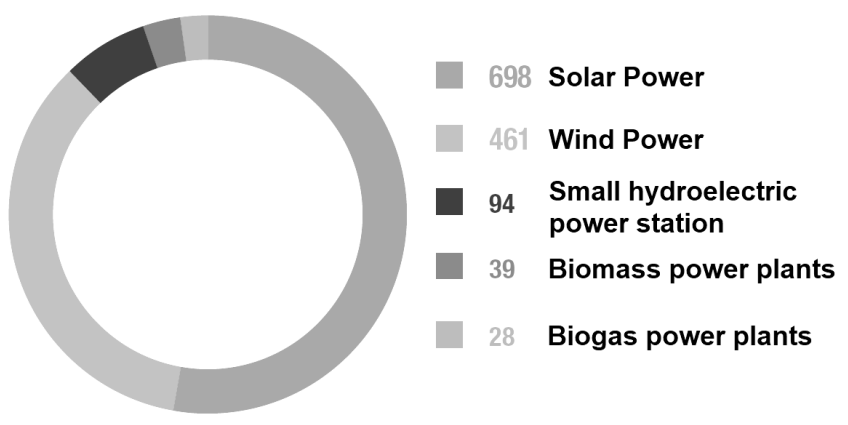

Fig. 4 - The structure of the Ukrainian renewable energy market by power, $M W$

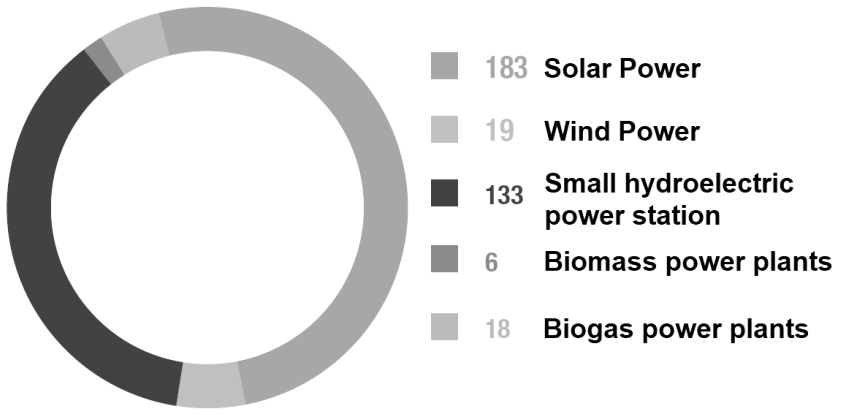

Fig. 5 - The structure of the Ukrainian renewable energy market by the number of stations, pcs

It is noteworthy that 15 of 183 SPPs account for about $20 \%$ of the total power of all SPPs. The largest SPP of Ukraine are installed in the following regions: Kropyvnytsky (125 MW), Novaya Kakhovka, Kherson region (120 MW), Kamenka, Cherkasy region (100 MW), Yavorov, Lviv region (57 MW), Priozernoe village, Odessa region (55 MW). The insolation map of Ukraine is presented in Figure 6.

Despite the fact that there is positive investment activity in the direction of green energy, alternative sources still account for a small share in the total energy production - according to the State Agency for Energy Efficiency and Energy Saving of Ukraine [12], the figure is $1 \%$ in 2017 of the year. At the same time, the market's growth potential is significant: by joining the European Energy Community, the country has committed itself to increase the share of RES in the country's energy balance to $11 \%$ by 2020 .

As in most countries, state policy in Ukraine as a whole acts as a key driver for the development of electricity generation based on renewable sources, and the so-called "green" tariff is a key incentive - a special tariff schedule according to which the state purchases electric energy from commercial organizations and individuals, generated using renewable sources. 


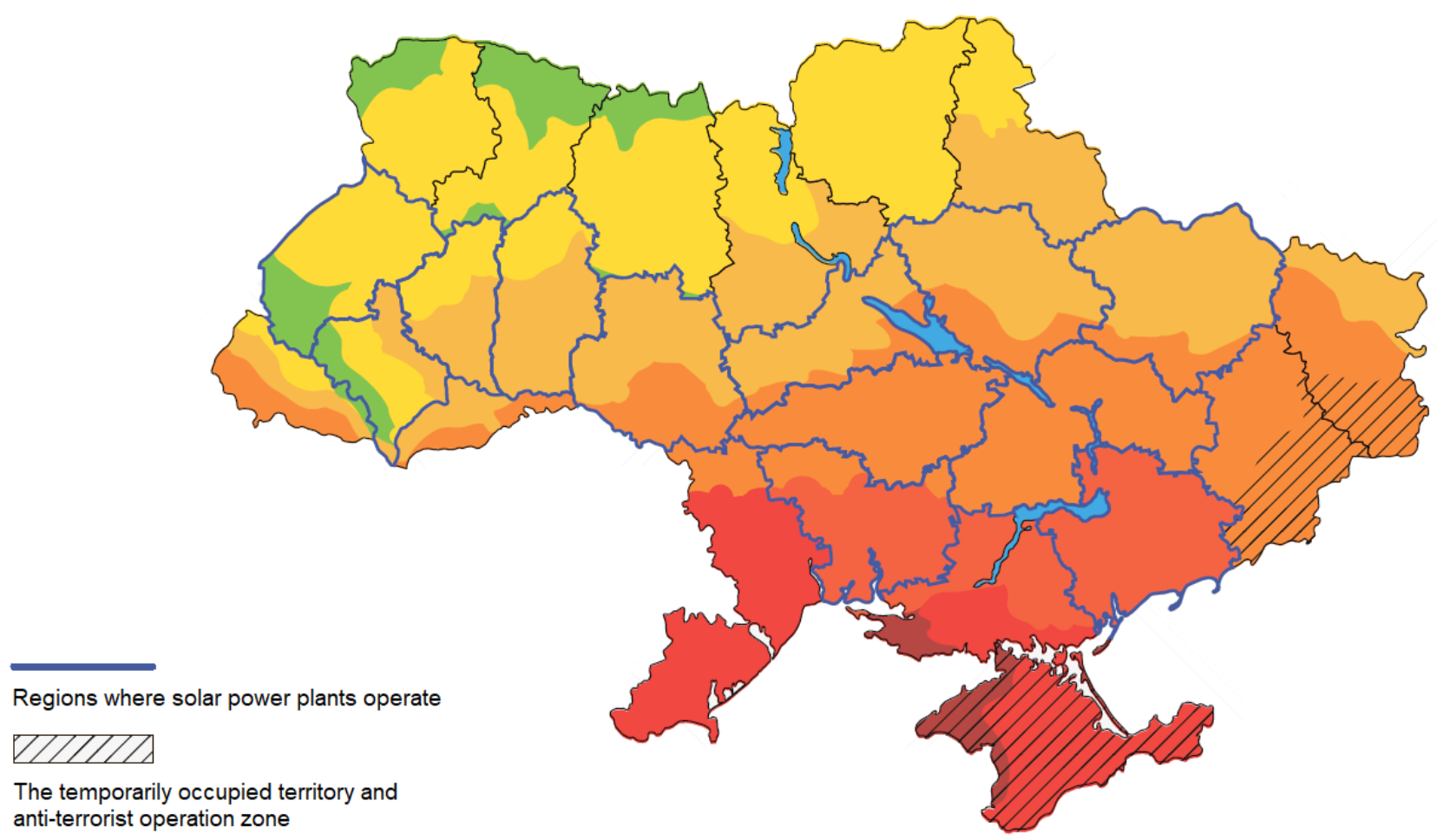
anti-terrorist operation zone

\begin{tabular}{|c|cccc}
\hline \multicolumn{5}{c}{ Solar Radiation Power, kW/m² per year } \\
\hline 1000 & 1100 & 1200 & 1300 & 1400
\end{tabular}

Fig. 6 - The insolation map of Ukraine

Having built and put into operation an industrial SPP in 2018, the generated electricity can be sold at 0.15 euros per $1 \mathrm{~kW}$ based on a long-term contract (table 2).

Table 2 - The rate of "green" tariff for solar power plants, eurocent $/ 1 \mathrm{~kW} \mathrm{~h}$

\begin{tabular}{|c|c|c|}
\hline Year & $\begin{array}{c}\text { The rate for } \\
\text { private solar } \\
\text { power with } \\
\text { power of up to } \\
30 \mathrm{~kW}\end{array}$ & $\begin{array}{c}\text { The rate for } \\
\text { industrial solar } \\
\text { power plants }\end{array}$ \\
\hline 2015 & 20 & 17 \\
\hline 2016 & 19 & 16 \\
\hline $2017-2019$ & 18 & 15 \\
\hline $2020-2024$ & 16,3 & 13,5 \\
\hline $2025-2030$ & 14,5 & 12 \\
\hline
\end{tabular}

\section{The structure of the renewable energy market of} Ukraine and the relationship of its participants

As a rule, the model of the energy market of developed countries suggests that the functions of the state are limited to regulation and tax collection. In Ukraine, the government agencies are direct market players [13]. Specifically, the State Company "Energorynok" is the only wholesale buyer and seller of electricity generating companies of all products (Fig. 7).

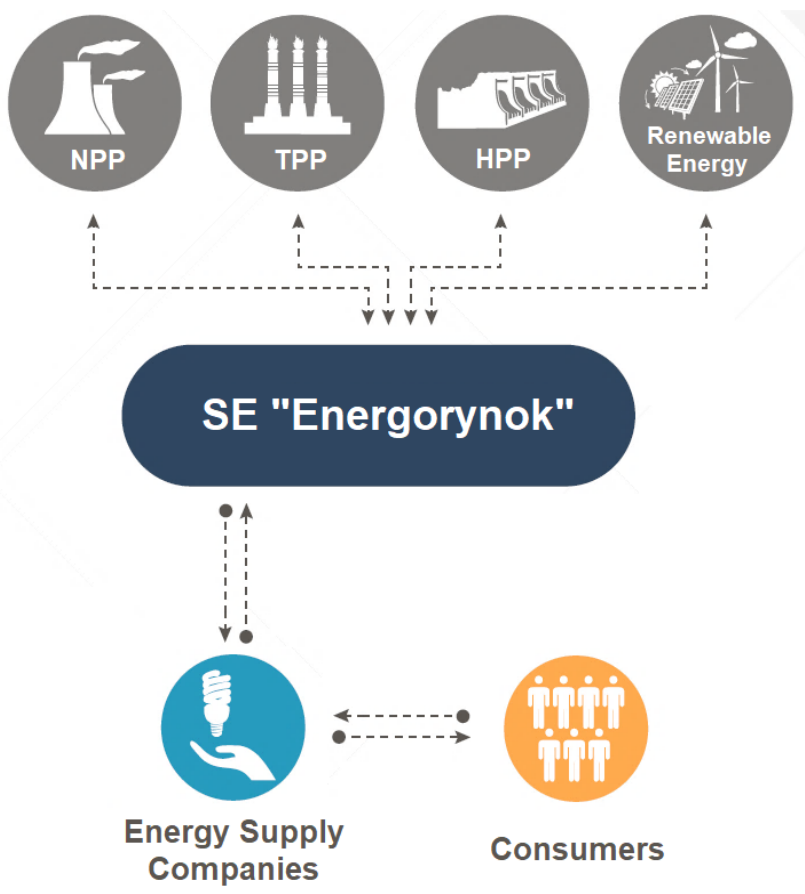

Fig. 7 - Scheme of functioning of the energy market of Ukraine

In addition, activities in this market are subject to licensing without fail and are approved by the relevant 
state regulator, namely NKREKU. Such a model actually limits the ability of SPP operators to use market mechanisms to strengthen the SPP commercial potential, including in the sphere of intensifying consumer demand. As a result, the main lever for increasing efficiency for SPP operators is operating expenses management.

Another lever to increase business profitability is to achieve synergy by combining projects for the generation of electricity and equipment trade activities in a single structure, as well as providing services in the field of installation and maintenance of SPP equipment. The services of design and industrial consulting are in demand.

The largest Ukrainian operators SPP consist of [14] group company Active Solar (in 2014 the company's assets are owned by CNBM - the largest Chinese producers of building materials) and "Rentehno" - the total power installed SPP is $232 \mathrm{MW}$ and $89 \mathrm{MW}$, respectively. The latter also provides industrial consulting services in foreign markets, helping clients in Europe and the Middle East.

Since only some types of components for SPP are produced in Ukraine, mainly equipment importers represent the Ukrainian market.

It is the largest company "Atmosphere", which has about 400 dealers in Ukraine, as well as representative offices in Moldova, Belarus, Latvia, Kazakhstan, and Kyrgyzstan. Components for their systems are imported from countries such as Poland, Italy, Turkey, China, Germany, and Taiwan.

Also, highlight the company "Alista" (Dnipro), which carries out import of components for SPP by "Altek" trademark. The company is also a key player in the service sector of such systems.

The suppliers of panels as basic components to the Ukrainian market are most often Chinese companies (in Asia, a significant part of the global production of photovoltaic cell components is currently located). In Ukraine, these products are represented by such brands as Suntech, UKSol, Q Cells, JA-Solar, Jinko, Q Cells, Perlight solar \& Abi-solar. Also in 2017, the market appeared panel produced by the American company First Solar. Inverters (an important element of photovoltaics) in Ukraine are represented by brands ABB, SOLIS, KSTAR, SMA, Huawei, FRONIUS, OMRON, SolarEdge.

In general, the SPP market is estimated as quite promising. The potential for growth of implementation power in operation is determined by the prospects of the action of "green" tariff. Now, the expected life of "green" tariff can successfully implement projects entering into operation of new facilities, managing to achieve a payback period.

\section{Investment attractiveness of solar energy projects in} Ukraine plant:
- Type of solar panels. The most common and effective ratio "price-quality" are the current panel on the cells of mono- or polycrystalline silicon, so the choice is usually made between these two types [15].

- Dependence of the level of insolation on the region. The most popular regions of Ukraine are Odessa, Dnipropetrovsk, Kherson, and Mykolajiv regions

- Orientation of solar panels on the side of light (south, north, west, east). Having the ability to rotate by using tracker mounting system, allowing generating 28$35 \%$ more energy than one hundred and stationary structures similar power (Fig. 8).

- The inclination of the solar panels relative to the horizon. A perpendicular incidence of sunlight on the panel is desirable, in the summer, this angle is $30-35^{\circ}$, in spring and autumn $-45^{\circ}$, and in winter, it is recommended to use an angle of $70^{\circ}$ relative to the horizon.

- Country-equipment supplier. Most Chinese use solar panels (as of $201781 \%$ of panels produced in the world is attributable to China), which significantly reduces the cost of SPP.

- Degradation of the equipment. Monocrystalline batteries in 25 years to lose $20 \%$ efficiency, and polycrystalline modules $-30 \%$, the warranty period of the equipment varies widely - from 5 to 25 years.

- Own power consumption and size of the object of other expenses.

- The selling price of electricity. Actual payback when calculating at 1 MW SPP [16]:

- Initial investments - 0.75 million Euros.

- Accessories - Chinese manufacturing class Tier 1.

- Payback period - 7 years.

- Annual income - 170 thousand Euros.

- The discount rate $-12,6 \%$.

- The internal rate of return - 19,1\%.

The project reaches breakeven only if the "green" tariff is in effect (the tariff rate for industrial SPP put into operation before 2019 is 0.15 eurocents).

\section{Solar energy market trends in Ukraine}

- In the years 2019-2020 is announced the completion of the SPP many construction projects in Ukraine, Canadian, Lithuanian, Indian, Slovenian and Chinese companies.

- JSC "Oschadbank" plans to invest 27.5 million Euros for the construction of solar power plants of 35 MW in the Dnipropetrovsk region (now is under construction).

- Rodina Energy Group Ltd (Rodina) \& Enerparc AG plans to launch the first solar energy project in the exclusion zone of the Chornobyl nuclear power plant; the station will have a capacity of $1 \mathrm{MW}$.

- The implementation of the Chornobyl Solar project, which is developing the State Agency of Ukraine for the Management of the Exclusion Zone, is ongoing. 


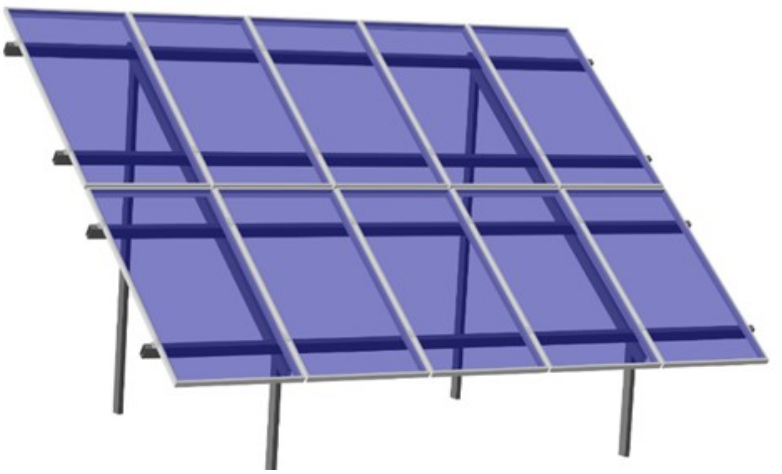

a)

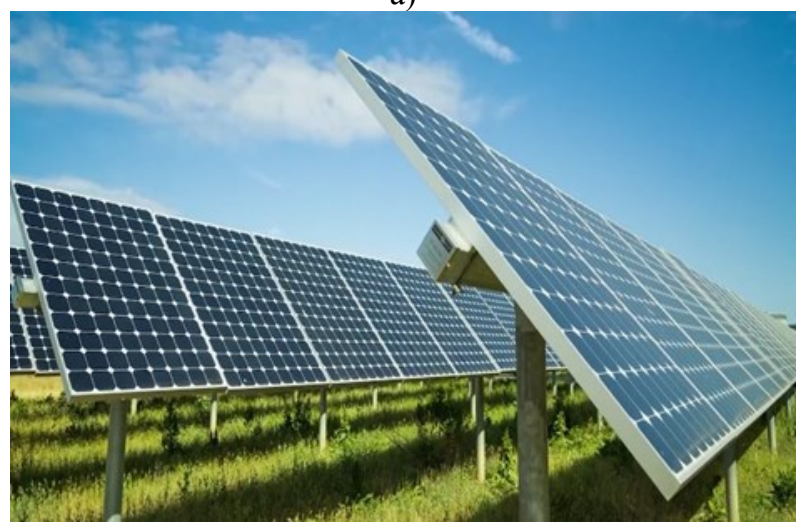

b)

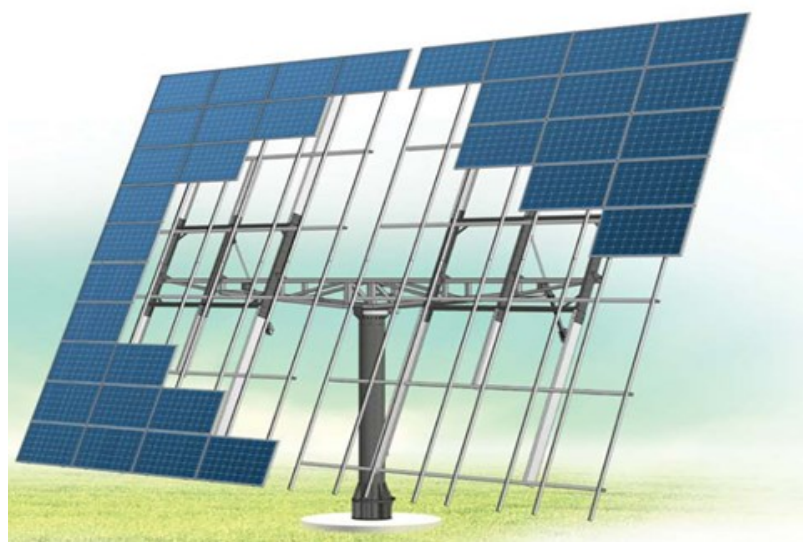

c)

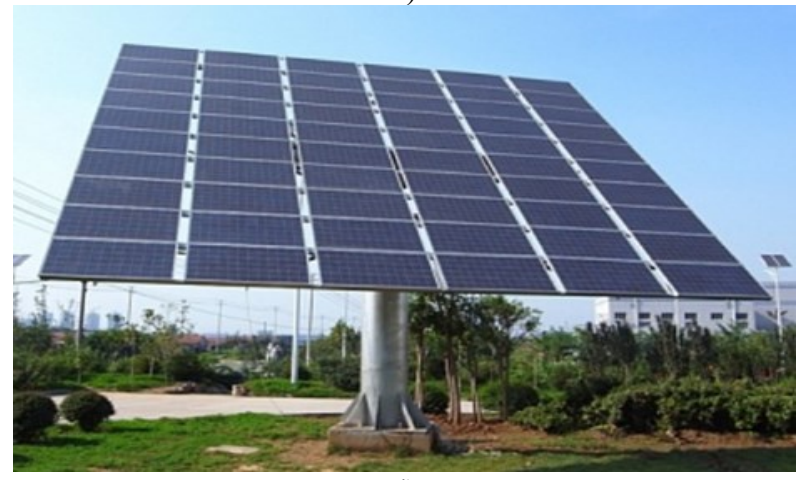

d)

Fig. 8 - Stationary engine placement of solar panels (a, b), the angle of which changes several times a year, and a tracking system for the sun $(c, d)$, the angle of which is adjusted every couple of minutes, providing a perpendicular drop of sunlight
The initiators of the SPP construction projects expect the government to adhere steadily to the implementation of the "Energy Strategy of Ukraine until 2035 ", according to which the share of renewable energy should reach $11 \%$ in gross final consumption by 2020 , and $20 \%$ by 2035 . Moreover, therefore, they will not cancel the action of the "green" tariff.

In the context of the competitive potential of SPP projects, their significant mobility should be mentioned. Unlike energy generators from traditional sources, which are rigidly attached to an existing site, the solar power plant is relatively quickly dismantled and can be remounted in another place, if the appropriate infrastructure is available. However, now, this advantage is not relevant, since there is no practice of direct contracts with consumers.

Further development of the market will be determined by the factors presented in table 3 .

Table 3 - Opportunities and barriers for operators SPP

\begin{tabular}{|c|c|}
\hline Opportunities & Barriers \\
\hline $\begin{array}{l}\text { - The advantages of } \\
\text { geography and climate; } \\
\text { • An attractive "green" } \\
\text { tariff rate for investors: } \\
0.15 \text { eurocents/kWh for } \\
\text { industrial plants and about } \\
0.18 \text { eurocents/kWh for } \\
\text { home stations, while at the } \\
\text { global level, countries are } \\
\text { already moving away from } \\
\text { the state policy of financial } \\
\text { incentives for RES; } \\
\text { - Positive dynamics of } \\
\text { lending to renewable energy } \\
\text { projects by the EBRD (30\% } \\
\text { of the total amount in the } \\
\text { amount of } 300 \text { million } \\
\text { euros); } \\
\text { - In } 2017 \text {, a number of } \\
\text { laws aimed at the } \\
\text { development of alternative } \\
\text { energy were also adopted, } \\
\text { namely bill No. } 4334 \text { - to } \\
\text { stimulate heat production } \\
\text { from alternative sources and } \\
\text { bill No. } 6081 \text { - to improve } \\
\text { investment opportunities in } \\
\text { the production sector. }\end{array}$ & $\begin{array}{l}\text { - Instability of the } \\
\text { regulatory framework of } \\
\text { state regulation of the } \\
\text { market; } \\
\text { - The probability of a } \\
\text { reduction or cancellation } \\
\text { of "green" tariff for the } \\
\text { already constructed power } \\
\text { plants, which could } \\
\text { negatively affect investor } \\
\text { confidence; } \\
\text { - A complex system of } \\
\text { obtaining permits and } \\
\text { approvals to operators } \\
\text { SPP; } \\
\text { - Inconsistency level of } \\
\text { technological } \\
\text { infrastructure originally } \\
\text { designed for conventional } \\
\text { energy sources, as a result } \\
\text { of such transmission lines } \\
\text { will not be able to build } \\
\text { their own capacity; } \\
\text { - SPP occupy large } \\
\text { areas - each } 1 \text { MW of } \\
\text { power requires } \\
\text { minimum of } 1.5 \text { hectares } \\
\text { of land. }\end{array}$ \\
\hline
\end{tabular}

A further increase in the number of projects in the field of solar energy in Ukraine will continue, because the fixed current rate of the "green" tariff, coupled with the constantly decreasing cost of equipment for solar plants, provides a relatively quick return on investment with minimal risk. In 2018-2019, there has been an acceleration in the rate of commissioning of new SPPs, since stations commissioned after 2019 will be able to 
count on a green tariff, which will already be $10 \%$ less than the current one. In fact, only in 2018 about 400 MW of solar energy was installed and commissioned in Ukraine, which increased the Ukrainian market of SPP by $57 \%$.

\section{Conclusions}

The development of the solar energy market is expected against the background of the introduction of new facilities will contribute to the development of new market niches, such as after-sales service, as well as the transformation of existing business models.

There is a possibility that in the future Ukraine will switch to the practice of concluding direct contracts, which implies that consumers conclude contracts directly with electricity producers on a competitive basis. This will allow SPP operators to implement a competitive pricing policy. In this case, the SPP mobility factor will also become significant. It is expected that such a development of the situation will not only stimulate the introduction of new stations by Ukrainian operators, but will also help attract SPP operators from other countries to Ukraine, especially if the state does not limit their ability to enter the local energy market.

\section{Список літератури}

1. British Petroleum Outlook. - 2018. - URL: http://bp.com/energyoutlook.

2. International Energy Agency. World Energy Outlook. 2018. - URL: https://www.iea.org.

3. Lazard's Levelized Cost of Energy ("LCOE") analysis Version 12.0. - URL: https://www.lazard.com.

4. Kreston GCG. Как заработать на солнце? Обзор рынка солнечной энергетики. Analitical Review. - 2018. - URL: https://kreston-gcg.com.

5. Bloomberg New Energy Finance. New Energy Outlook. 2019. - URL: https://bnef.com.

6. Frost \& Sullivan's. Global Renewable Energy Outlook. 2018. - URL: https://frost.com.

7. Сокол, Е. И. Физико-технические особенности и предельные практические возможности фотоэнергетического модуля нового поколения на территории Украины / Е. И. Сокол, В. Р. Копач, Р. В. Зайцев, М. В. Кириченко, А. В. Мериуц, Г. С. Хрипунов // Відновлювана енергетика. - 2011. - № 2 (25). - С. 18-28.

8. Мачулін, В. Сонячна енергетика: порядок денний для світу й України / В. Мачулін, В. Литовченко, М. Стріха // Вісник національної академії наук України. 2011. - № 5. - C. 30-39.

9. IB Centre Inc. - URL: http://www.ibcentre.tech.

10. National Energy and Utilities Regulatory Commission of Ukraine. - URL: http://www.nerc.gov.ua.

11. Майстро, С. В. Концептуальні засади стратегії державного регулювання та перспективи розвитку альтернативної енергетики в Україні / С. В. Майстро // Теорія та практика державного управління. - 2015. №. 3(50). - C. 100-106.

12. State Agency on Energy Efficiency and Energy Saving of Ukraine. - URL: http://saee.gov.ua.
13. Процюк, Т. Б. Реформирование рынка электрической энергии Украины с учётом опыта зарубежных стран / T. Б. Процюк // Науковий вісник Херсонського державного університету. Серія Економічні науки. - 2014. - Вип. 5., Ч. 1. - С. 246-249.

14. Кудря, С. О. Стан та перспективи розвитку відновлюваної енергетики в Україні / С. О. Кудря // Вісник начіональної академії наук України. - 2015. - № 12. - С. 19-26.

15. Зайцев, Р. В. Вплив робочої температури на ефективність промислових зразків кремнієвих фотоелектричних перетворювачів китайського виробництва / Р. В. Зайцев, М. В. Кіріченко, Г. С. Хрипунов, Л. В. Зайцева // Відновлювальна енергетика. - 2017. - №. 3(50). - С. 35-41.

16. Кожем'яко, В. П. Оптимізація проектів будівництва сонячних електростанцій із врахуванням базових техніко-економічних показників / В. П. Кожем'яко, О. Г. Домбровський, В. І. Маліновський // Оптикоелектронні пристрої та компоненти в лазерних $i$ енергетичних технологіях. - 2015. - №. 2. - С. 66-81.

\section{References (transliterated)}

1. British Petroleum Outlook, 2018. - Available at: $\mathrm{http}: / /$ bp.com/energyoutlook.

2. International Energy Agency. World Energy Outlook, 2018. - Available at: https://www.iea.org.

3. Lazard's Levelized Cost of Energy ("LCOE") analysis Version 12.0. - Available at: https://www.lazard.com.

4. Kreston GCG. Как заработать на солнце? Обзор рынка солнечной энергетики. Analitical Review, 2018. Available at: https://kreston-gcg.com.

5. Bloomberg New Energy Finance. New Energy Outlook, 2019. - Available at: https://bnef.com.

6. Frost \& Sullivan's. Global Renewable Energy Outlook, 2018. - Available at:https://frost.com.

7. Sokol, E. I., Kopach, V. R., Zaitsev, R. V., Kirichenko, M. V., Meriuts, A. V., Khrypunov, G. S. Fizikotekhnicheskiye osobennosti i predel'nyye prakticheskiye vozmozhnosti fotoenergeticheskogo modulya novogo pokoleniya na territorii Ukrainy [Physicotechnical features and ultimate practical capabilities of a new generation photovoltaic module in Ukraine]. Vidnovlyuvana energetika [Renewaqble energy], 2011, 2(25), 18-28.

8. Machulin, V., Litovchenko, V., Striha, M. Sonyachna enerhetyka: poryadok dennyy dlya svitu y Ukrayiny [Solar energy: an agenda for the world and Ukraine]. Visnyk natsional'noyi akademiyi nauk Ukrayiny [Bulletin of the National Academy of Sciences of Ukraine], 2011, 5, 30-39.

9. IB Centre Inc. - Available at: http://www.ibcentre.tech.

10. National Energy and Utilities Regulatory Commission of Ukraine. - Available at: http://www.nerc.gov.ua.

11. Maystro, S. V. Kontseptual'ni zasady stratehiyi derzhavnoho rehulyuvannya ta perspektyvy rozvytku al'ternatyvnoyi enerhetyky $\mathrm{v}$ Ukrayini [Conceptual bases of the state regulation strategy and prospects of alternative energy development in Ukraine]. Teoriya ta praktyka derzhavnoho upravlinnya [Public administration theory and practice], 2015, 3(50), 100-106.

12. State Agency on Energy Efficiency and Energy Saving of Ukraine. - Available at: http://saee.gov.ua.

13. Protsuk, T. B. Reformirovaniye rynka elektricheskoy energii Ukrainy s uchotom opyta zarubezhnykh stran [Reforming the electric energy market of Ukraine taking into account the experience of foreign countries]. Naukovyy 
visnyk Khersons'koho derzhavnoho universytetu. Seriya Ekonomichni nauky [Scientific Bulletin of Kherson State University. Series Economic Sciences.], 2014, 5(1), 246249.

14. Kudria, S. O. Stan ta perspektyvy rozvytku vidnovlyuvanoyi enerhetyky $\mathrm{v}$ Ukrayini [Status and prospects of renewable energy development in Ukraine]. Visnyk natsional'noyi akademiyi nauk Ukrayiny [Bulletin of the National Academy of Sciences of Ukraine], 2015, 12, 1926.

15. Zaitsev, R. V., Kirichenko, M. V., Khrypunov, G. S., Zaitseva, L. V. Vplyv robochoyi temperatury na efektyvnist' promyslovykh zrazkiv kremniyevykh fotoelektrychnykh peretvoryuvachiv kytays'koho vyrobnytstva [Effect of operating temperature on the efficiency of industrial designs of Chinese silicon photoelectric converters]. Vidnovlyuvana energetika [Renewaqble energy], 2017, 3(50), 35-41.

16. Kozhemyako, V. P. Optymizatsiya proektiv budivnytstva sonyachnykh elektrostantsiy iz vrakhuvannyam bazovykh tekhniko-ekonomichnykh pokaznykiv [Optimization of solar power plant construction projects taking into account basic technical and economic indicators]. Optyko-elektronni prystroyi ta komponenty $v$ lazernykh $i$ enerhetychnykh tekhnolohiyakh [Opto-electronic devices and components in laser and energy technologies], 2015, 2, 66-81.

\section{Сведения об авторах (About authors)}

Зайцев Роман Валентинович- доктор технічних наук, доцент, Національний технічний університет «Харківський політехнічний інститут», завідувач кафедри фізичного матеріалознавства для електроніки та геліоенергетики; м. Харків, Україна; ORCID: 0000-0003-2286-8452; e-mail: zaitsev@khpi.edu.ua.

Roman Zaitsev - Doctor of Engineering Science, Docent, Head of Department, Materials for Electronics and Solar Cells Department, National Technical University “Kharkiv Polytechnic Institute”, Kharkiv, Ukraine; e-mail: zaitsev@khpi.edu.ua.

Мінакова Ксенія Олександрівна - кандидат фізико-математичних наук, Національний технічний університет «Харківський політехнічний інститут», доцент кафедри фізики; м. Харків, Україна; ORCID: 0000-0002-8869-1082; e-mail: minakova_kseniia@khpi.edu.ua.

Kseniia Minakova - Ph. D., Associate Professor, Physics Department, National Technical University "Kharkiv Polytechnic Institute", Kharkiv, Ukraine; e-mail: minakova_kseniia@khpi.edu.ua.

Будь ласка, посилайтесь на ию статтю наступним чином:

Зайцев, Р. В. Огляд ринку сонячної енергетики України: стан та комерційні перспективи / Р. В. Зайцев, К. О. Мінакова // Вісник НТУ «ХПI», Серія: Нові рішення в сучасних технологіях. - Харків: НТУ «ХПІ». - 2019. - № 1. - С. 20-28. - doi:10.20998/2413-4295.2019.01.03.

Please cite this article as:

Zaitsev, R., Minakova, K. Overview of the Ukrainian solar market: status and commercial perspectives. Bulletin of NTU "KhPI". Series: New solutions in modern technologies. - Kharkiv: NTU "KhPI", 2019, 1, 20-28, doi:10.20998/24134295.2019.01.03.

Пожалуйста, ссылайтесь на эту статью следующим образом:

Зайцев, Р. В. Обзор рынка солнечной энергетики Украины: состояние и коммерческие перспективы / Р. В. Зайцев, К. О. Минакова // Вестник НТУ «ХПИ», Серия: Новые решения в современных технологиях. - Харьков: НТУ «ХПИ». 2019. - № 1. - С. 20-28. - doi:10.20998/2413-4295.2019.01.03.

АННОТАЦИЯ Сегодня многие называют солнечную энергию энергией будущего, и многие компании вкладывают значительные инвестиции в строительство таких электростанций. В статье приведен обзор коммерческих перспектив этого рынка, определены размеры инвестиций и окупаемость проекта. Современные солнечные батареи в состоянии работать без дополнительных капиталовложений десятки лет и, с точки зрения авторов, в долгосрочной перспективе электроэнергия, сгенерированная таким образом, станет не просто рентабельной, а сверхприбыльной. B статье рассмотрена глобальная ситуация в сфере рынка энергетики и в сфере возобновляемых источников энергии, в частности. Пояснены причины, которые послужили толчком в развитии возобновляемых источников энергии, ключевыми из которых являются опасность атомной энергетики и загрязнение окружающей среды. На ряду с указанным, рассмотрена структура рынка возобновляемых источников энергии на Украине, географическое расположение которой благоприятно для реализачии проектов солнечной энергетики. Для климата Украины характерно большое количество солнечных дней: по степени инсоляции Украина значительно превосходит европейских лидеров в солнечной энергетике. Указанное является базовым фактором, позволяющим говорить о коммерческих перспективах проектов солнечной электрогенерачии, реализуемых в Украине. На фоне указанных перспектив рассмотрена структура энергетического рынка на Украине и инвестиционная привлекательность проектов возобновляемой энергетики. Обсуждены рыночные тенденции развития рынка солнечной энергетики, которые, как ожидается, на фоне ввода новых объектов будут способствовать развитию новых рыночных ниш, таких как сервисное обслуживание, а также трансформации существующих бизнес-моделей.

Ключевые слова: солнечная энергетика; возобновляемые источники энергии; обзор рынка Украины; коммерческие перспективы 